\title{
Aspek Employe Engagement Guru Dilihat dari Model Kepemimpinan Kepala Sekolah
}

\author{
Anita Diyah Sitawati ${ }^{1}$, Nurodin Usman ${ }^{2}$ \\ 1 Universitas Muhammadiyah Magelang \\ 2 Universitas Muhammadiyah Magelang
}

\section{ARTICLE INFO}

\section{Article History:}

Received: 10 September 2021

Revised: 08 November 2021

Accepted: 10 Desember 2021

Published: 30 Desember 2021

\section{Keywords: \\ Employe Engagement; \\ Guru; \\ Model Kepemimpinan.}

\begin{abstract}
PT)
Employe Engagement is one of the important aspects for employees in completing work that can improve performance. Employe Engagement is influenced by the leadership model displayed by leaders at the institution. This study is explanatory research. The research approach used is the quantitative approach. The sample in the study was 200 people. The data analysis techniques used are: (1) Descriptive Analysis; and (2) Multiple Linear Regression Analysis. The results of this study showed that (1) Teachers have employe engagement, $51 \%$ of respondents (102 teachers) have excellent employe engagement, $49 \%$ (98 teachers) have employe engagement well, 5\% (10 teachers) have employe engagement is not good; (2) Teachers have different perceptions of headteacher leadership, 55\% (110 teachers) state head leadership has transformative leadership model, $44 \%$ (87 teachers) state headmaster leadership has Charismatic leadership model, 1\% (2 teachers) states headmaster leadership has Transactional leadership model; (3) The influence of the principal's leadership model on employe angegement of teachers can be seen that the proportion of the charismatic leadership influence of principals on Employe Angegement shows a figure of 20.5 percent and the proportion of the transformative leadership influence of principals on employe angegement teachers by $34.1 \%$, and the proportion of transactional leadership influence of principals to Employe Angegement by 4.1 percent.
\end{abstract}

Employe Engagement merupakan salah satu aspek yang penting bagi pegawai dalam menyelesaikan pekerjaan yang mampu meningkatkan kinerja. Employe Engagement salah satunya dipengaruhi oleh model kepemimpinan yang ditampilkan oleh leader pada lembaga tersebut. Penelitian ini merupakan penelitian explanatory. Pendekatan penelitian yang digunakan adalah pendekatan kuantitatif. Sampel dalam penelitain sebanyak 200 orang. Teknik analisis data yang digunakan adalah : (1) Analisis Deskriptif; dan (2) Analisis Regresi Linier Berganda. Hasil penelitian ini menunjukkan bahwa (1) Guru memiliki Employe Engagement variative, 51\% responden (102 guru) memiliki Employe Engagement sangat baik, 49\% (98 guru) memiliki Employe Engagement baik, 5\% (10 guru) memiliki Employe Engagement kurang baik; (2) Guru memiliki persepsi yang berbeda-beda tentang kepemimpinan kepala sekolah, 55\% (110 guru) menyatakan kepemimpinan kepala memiliki model kepemimpinan Transformatif, 44\% (87 guru) menyatakan kepemimpinan kepala sekolah memeiliki model kepemimpinan Kharismatik,1\% (2 guru) menyatakan kepemimpinan kepala sekolah memiliki model kepemimpinan Transaksional; (3) Pengaruh model kepemimpinan kepala sekolah terhadap Employe Angegement guru dapat dilihat bahwa Proporsi pengaruh kepemimpinan kharismatik kepala sekolah terhadap Employe Angegement menunjukkan angka sebesar 20,5 persen dan Proporsi pengaruh kepemimpinan transformatif kepala sekolah terhadap Employe Angegement guru sebesar $34,1 \%$, serta Proporsi pengaruh kepemimpinan transaksional kepala sekolah terhadap Employe Angegement 4,1\%.

Corresponding Author:

Anita Diyah Sitawati,

Email: anitadiyah881@gmail.com

How to Cite: Sitawati, A.D., Usman, N. (2021). Aspek-Aspek Employe Engagement Guru Dilihat dari Model Kepemimpinan Kepala Sekolah. Sosio e-kons, 13 (03), 145-157 


\section{PENDAHULUAN}

Pendidikan memiliki peran yang penting dalam membentuk karakter sebuah bangsa. Hal tersebut dikarenakan pendidikan merupakan salah satu cara untuk meningkatkan kualitas sumber daya manusia. Apabila pendidikan tersebut memiliki kualitas yang baik, maka dapat berpengaruh terhadap perkembangan manusia dan pada keseluruhan aspek kepribadian manusia tersebut. salah satu perangkat yang berperan dalam mewujudkan tugas untuk mendidik dan membangun karkter bangsa ini terdapat di tangan tenaga kerja pendidik yang dikenal sebagai guru. Adanya guru yang berkualitas dapat menunjang keberhasilan kegiatan belajar di lembaga pendidikan (Rizqiani, Syamsun, \& Dirdjosuparto, 2011). Pada hakekatnya guru yang berkualitas adalah guru yang memiliki kinerja yang baik dan memiliki keterikatan terhadap institusi atau lembaga, serta memiliki dedikasi dan pengabdian (Ni Luh Putu Astuti, Ni Putu Sri Harta Mimba, 2016). Dalam bahasa lain, sosok guru seperti ini adalah guru yang memiliki Employ engagement. Employ Engagement adalah hal yang penting bagi guru untuk meningkatkan dan mempertahankan kualitas pendidikan (Eka Dian Aprilia, 2020).

Employe Engagement merupakan keadaan mental yang positif, memuaskan dan berhubungan dengan pekerjaan yang dicirikan dengan adanya kekuatan (vigor), dedikasi (dedication) dan pengabdian (absorption). Kahn 1990 dalam May et al., 2004 employe engagement dalam pekerjaan dikonsepsikan sebagai anggota organisasi yang melaksanakan peran kerjanya, bekerja dan mengekspresikan dirinya secara fisik, kognitif dan emosional selama bekerja. Bakker et al. (2006) menyatakan bahwa seseorang yang mempunyai employe engagement yang tinggi cenderung lebih kreatif, lebih produktif dan mau bekerja ekstra. Employe engagement yang demikian itu sangat diperlukan untuk mendorong timbulnya semangat kerja karyawan (Hochschild, 1983 dalam May et al., 2004) sehingga berpengaruh positif pada kinerja (Ni Luh Putu Astuti, Ni Putu Sri Harta Mimba, 2016).

Schaufeli et al. (2002) mendefinisikan keterikatan kerja sebagai suatu kondisi mental yang positif terkait dengan pekerjaan yang mempunyai karakteristik (a) semangat, (b) dedikasi, dan (c) penghayatan. Semangat ditandai oleh energi dan ketahanan mental tingkat tinggi saat bekerja, kemauan untuk menginvestasikan upaya dalam pekerjaanseseorang, dan kegigihan bahkan dalam menghadapi kesulitan. Dedikasi mengacu pada keterlibatan kuat dalam pekerjaan seseorang, merasa bahwa pekerjaannya penting, antusiasme, inspirasi, kebanggaan, dan tantangan. Lebih lanjut, penghayatan ditandai dengan sepenuhnya terkonsentrasi dan tenggelam dalam pekerjaan, di mana waktu berlalu dengan cepat (Ike Agustina, 2020). Pegawai yang memiliki Employe Engagement yang lebih tinggi, akan cenderung lebih kreatif, lebih produktif dan mau untuk bekerja ekstra. Merujuk pada beberapa hasil penelitian dapat disimpulkan bahwa employe engagement merupakan salah satu aspek yang penting ada bagi setiap pegawai dalam menyelesaikan pekerjaan mereka yang diyakini mampu meningkatkan kinerjanya. Logikanya employe engagement itu mesti ada pada setiap pegawai (Ni Luh Putu Astuti, Ni Putu Sri Harta Mimba, 2016).

Employee Engagement merupakan sikap positif yang dimiliki oleh karyawan, yaitu meliputi loyalitas dan kebanggaan atas organisasi. Employee engagement merupakan keyakinan yang dimiliki oleh karyawan atas keterlibatannya dalam keberhasilan organisasi (Sisly Duri Afryana, 2018). Employee Engagement merupakan suatu upaya pemberdayaan karyawan atas dedikasinya terhadap organisasi. Employee engagement merupakan bentuk keterikatan karyawan baik secara psikis maupun secara fisik yang digunakan dalam menyelesaikan peran organisasional. Sedangkan menurut The Institute for Employment Studies, Employee Engagement merupakan kesadaran karyawan dalam bekerja dengan rekan-rekan kerja untuk meningkatkan kinerja agar bermanfaat bagi organisasi (Santosa, 2012). 
Employee Engagement sebagai peran serta dan antusiasme untuk bekerja yang berkaitan dengan rasa keterikatan emosional yang positif dan komitmen karyawan. Engagement, terjadi ketika seseorang merasa bernilai, menikmati dan percaya pada pekerjaan yang mereka lakukan. Dapat disimpulkan bahwa Employee Engagement merupakan suatu sikap positif karyawan dengan organisasi mereka karena seorang karyawan senang dan antusias melakukan pekerjaan mereka, mendapatkan kepercayaan dari atasan dan merasa dihargai kontribusi mereka dalam organisasi, keterkaitan itu diwujudkan dengan kontribusi yang melebihi apa yang diharapkan oleh organisasi terhadap mereka dan menghasilkan karyawan yang bisa berkomitmen dalam menyelesaikan pekerjaannya (Pandu Djati Sentano, Sugih Arijanto, 2016).

Dimensi Keterikatan guru yang memiliki Employee Engagement yang baik adalah sebagai berikut (Bakker dan Schaufeli, 2003): (1) Kekuatan (Vigor), yaitu Kekuatan dikarakteristikkan dengan energi dan resiliensi mental yang tinggi ketika sedang bekerja, kemauan berusaha sungguh-sungguh dalam pekerjaan dan gigih dalam menghadapi kesulitan. Individu dengan skor tinggi pada aspek kekuatan biasanya memiliki energi dan stamina tinggi serta bersemangat ketika bekerja. Sedangkan individu dengan skor rendah pada aspek kekuatan memiliki tingkat energi, semangat dan stamina yang rendah saat bekerja; (2) Dedikasi (Dedication), yaitu dedikasi yang mengacu pada perasaan yang penuh makna, antusias, inspirasi, kebanggaan dan tantangan. Individu yang memiliki skor tinggi pada aspek dedikasi secara kuat mengidentifikasi diri dengan pekerjaan karena adanya pengalaman bermakna, menginspirasi dan menantang. Selain itu, mereka selalu antusias dan bangga dengan pekerjaannya. Sedangkan individu dengan skor rendah tidak mengidentifikasi diri dengan pekerjaannya karena tidak memiliki pengalaman yang bermakna, menginspirasi dan menantang; (3) Keasyikan (Absorption). Absorpsi atau keasyikan dikarakteristikkan dengan konsentrasi penuh, minat terhadap pekerjaan dan sulit melepaskan diri dari pekerjaan. Individu yang memiliki skor tinggi pada aspek absorpsi biasanya merasa tertarik dengan pekerjaan dan sulit untuk melepaskan diri dari pekerjaannya, begitupun sebaliknya.

Secara logika seberapapun tinggi Employe Engagement yang dimiliki pegawai jika pimpinan tidak pernah memberikan perhatian, tidak memberikan motivasi dan tidak memberikan contoh dan perilaku yang positif akan memungkinkan bisa menurunkan kinerja staf. Begitu juga sebaliknya pegawai yang memiliki Employe Engagement yang tinggi, jika mendapat dukungan dari pimpinan yang selalu memberikan motivasi, memberikan perhatian dan selalu memberikan contoh dan perilaku yang positif akan mendukung staf mengoptimalkan kinerjanya (Ni Luh Putu Astuti, Ni Putu Sri Harta Mimba, 2016).

Oleh kerena itu faktor yang mendasari terbentuknya engagement adalah kualitas leadership yang berdampak pada adanya perasaan pegawai untuk dihargai dan keterlibatannya di dalam organisasi. Hal tersebut sangat penting bagi pemimpin agar peduli terhadap pegawainya, memperlakukan pegawai secara adil, memberi semangat dan informasi, serta membantu pegawai untuk berkembang melalui pelatihanpelatihan (Viqi Anggreana, 2015).

Kepemimpinan sebagai proses mempengaruhi orang lain agar mereka dapat mengerti dan menyetujui tentang apa yang harus dilakukan dan bagaimana cara melakukannya, dan juga proses memfasilitasi upaya individu dan kelompok untuk mencapai tujuan bersama (Lianto Vilency Virani, 2015).

Kepemimpinan merupakan proses pengelolaan, pemberdayaan, dan pengawasan yang dilakukan pemimpin terhadap hal yang dipimpinnya, berujung pada peningkatan sumberdaya manusia untuk mencapai tujuan bersama (Prasetyono \& Ramdayana, 2020). Secara umum, kepemimpinan ditandai sebagai suatu proses meliputi; mempengaruhi, mengarahkan, mengontrol tingkah laku dan emosional pada anggota organisasi (Agustinus Hermino, 2014). Kepemimpinan adalah kegiatan untuk mempengaruhi orang lain agar mau bekerja dengan suka 
rela untuk mencapai tujuan kelompok. Menurut Cyriel O'Donnell, kepemimpinan adalah mempengaruhi orang lain agar ikut serta dalam mencapai tujuan umum (Tim Pengembang IImu Pendidikan FIP-UPI, 2007).

Pemimpin memiliki peranan yang dominan dalam sebuah organisasi.Peranan yang dominan tersebut dapat mempengaruhi moral kepuasan kerja keamanan, kualitas kehidupan kerja dan terutama tingkat prestasi suatu organisasi.Sebagaimana dikatakan Hani Handoko bahwa pemimpin juga memainkan peranan kritis dalam membantu kelompok organisasi, atau masyarakat untuk mencapai tujuan mereka (Hani Handoko, 1999).

Namun demikian, dalam memimpin sebuah lembaga, seorang leader memiliki gaya tersendiri (Prasetyono, Ramdayana, \& Estiningsih, 2020). Gaya-gaya yang dimiliki leader tersebut akan berbengaruh terhadap keterlibatan guru terhadap sekolah.

Pada hakekatnya, model kepemimpinan seorang leader terdiri dari beberapa model, yaitu: Pertama adalah Kepemimpinan Transaksional. Menurut Burns pada kepemimpinan transaksional, hubungan antara pemimpin dengan bawahan didasarkan pada serangkaian aktivitas tawar menawar antar keduanya. Karakteristik kepemimpinan transaksional adalah contingent reward dan management by-exception. Pada contingent reward dapat berupa penghargaan dari pimpinan karena tugas telah dilaksanakan, berupa bonus atau bertambahnya penghasilan atau fasilitas. Hal ini dimaksudkan untuk memberi penghargaan maupun pujian untuk bawahan terhadap upaya-upayanya. Selain itu, pemimpin betransaksi dengan bawahan, dengan memfokuskan pada aspek kesalahan yang dilakukan bawahan, menunda keputusan atau menghindari hal-hal yang kemungkinan mempengaruhi terjadinya kesalahan . Management by-exception menekankan fungsi managemen sebagai kontrol. Pimpinan hanya melihat dan mengevaluasi apakah terjadi kesalahan untuk diadakan koreksi, pimpinan memberikan intervensi pada bawahan apabila standar tidak dipenuhi oleh bawahan. Praktik management by-exception, pimpinan mendelegasikan tanggungjawab kepada bawahan dan menindaklanjuti dengan memberikan apakah bawahan dapat berupa pujian untuk membesarkan hati bawahan dan juga dengan hadiah apabila laporan yang dibuat bawahan memenuhi standar (Dwi Ari Wibawa, 2012).

Dalam prakteknya, kepemimpinan Transaksional memiliki ciri-ciri sebagai berikut: (1) Imbalan tergantung: mengontrakkan pertukaran imbalan untuk upaya, menjanjikan imbalan untuk kinerja yang baik, mengakui pretasi; (2) Manajemen dengan pengecualian (aktif): menjaga mencari penyimpangan dari aturan dan standar, pengambil tindakan koreksi; (3) Manajemen dengan pengecualian (pasif): hanya ikut campur jika standar tidak dipenuhi; dan (4) LaissazFaire: melepaskan tanggung jawab, menghindari pengambilan keputusan (Veithzal Rizai dan Arvian Arifi, 2015).

Kedua adalah Kepemimpinan Transformatif. Istilah kepemimpinan transformatif berasal dari dua kata, yaitu kepemimpinan atau leadership dan transformatif atau tranformasional. Istilah transformatif berinduk kepada kata to transfrom, yang bermakna mentranformatifkan atau mengubah sesuatu menjadi bentuk lain yang berbeda (Didin Kurniadi, 2012).

Kepemimpinan transformasional merupakan sebuah proses dimana pemimpin mengambil tindakan-tindakan untuk meningkatkan kesadaran rekan kerja mereka tentang apa yang penting, untuk meningkatkan kematangan motivasi rekan kerja mereka serta mendorong mereka untuk melampaui minat pribadi mereka demi mencapai kemaslahatan kelompok, organisasi, atau masyarakat (Raihan, n.d.).

Menurut Robbins \& Timothy, kepemimpinan transformatif (transformational leaders) adalah tipe pemimpin yang mengarahkan atau memotivasi para pengikutnya pada tujuan yang telah ditetapkan dengan cara memeperjelas peran dan tugas anggotanya. Pemimpin transformatif (transformational leaders) menginspirasi para pengikutnya untuk menyampaikan kepentingan 
pribadi mereka demi kebaikan organisasi dan mereka mampu memiliki pengaruh yang luar biasa pada diri para pengikutnya (Stephen P. Robbins \& Timothy A.Judge, 2008).

Asumsi mendasar tentang kepemimpinan transformasional yakni, bahwa pemimpin akan diikuti oleh orang lain bila dapat menginspirasi mereka, visioner, serta bijak dan 'menularkan' energi positif untuk mencapai suatu tujuan. Sehingga, bagi bawahan dalam kepemimpinan transformasional akan menjadikan mereka 'kaya' akan pengalaman berharga bersama pemimpinnya (transformasional), karena senantiasa diberikan semangat dan energi positif dari pimpinannya (Imam Mahalli, 2012).

Ciri-ciri kepemimpinan transformasional yaitu: (1) Mempengaruhi Secara Ideal. Dengan memberikan visi dan misi, menanamkan kebanggaan, serta mendapatkan respek dan kepercayaan; (2) Motivator yang Inspirasional. Menggunakan kekuasaan secara positif dan bertanggung jawab kepada perusahaan dan orang yang sedang dipimpin yang membutuhkan pengakuan, penghargaan, dan pencapaiannya untuk mendorong motivasi dan kepuasan; (3) Stimulator Intelektual. Meningkatkan kecerdasan, rasional dan pemecahan masalah yang cermat. Kepemimpinan transformatif selalu terbuka akan potensi pemahaman yang lebih mendalam atau lebih tinggi terhadap kenyataan di masa depan dibandingkan dengan kenyataan yang ada saat ini; (4) Pertimbangan yang Bersifat Individual. Memberikan perhatian pribadi, memberlakukan masing-masing karyawan secara individual, serta melatih dan memberikan saran (Stephen P. Robbins \& Timothy A.Judge, 2008).

Kepemimpinan transformatif memiliki beberapa manfaat bagi sebuah organisasi ialah (Husaini Usman, 2014): (1) Menciptakan dan mengkomunilasikan visi dan tujuan; (2) Melaksanakan pemikiran dan perencanaan strategis dan fleksibel; 3) Memfasilitasi rekan kerja, bawahan, dan perkembangan tim; (4) Memfasilitasi perkembangan organisasi. 5) Melindungi individu dari kekuatan yang merusak; (6) Melindungi organisasi dari kekuatan yang merusak; (7) Mencari dan mengkomunikasikan konsesnsus antar tim; (8) Mengspesifikasi pedoman hidup, nilai-nilai, dan menciptakan budaya; (9) Menciptakan cara pandang; dan (10) Memotivasi orangorang untuk bertindak.

Ketiga adalah Kepemimpinan Kharismatik. Kepemimpinan kharismatik adalah suatu kemampuan untuk menggerakkan ornag lain dengan mendayagunakan kelebihan atau keistimewaan dalam sifat kepribadian yang dimiliki oleh seorang pemimpin (Sondang P.Siagian, 2009).

Dalam pandangan Conger dalam bukunya Kompri, kepemimpinan karismatik mengedepankan kewibawaan diri seorang pemimpin, yang di tunjukan oleh rasa tanggung jawab yang tinggi kepada bawahanya. Kepekaan dan kedekatan pemimpin karismatik dengan bawahanya di sebabkan karisma/kewibawaan pribadi (personal power) pemimpin untuk menumbuhkan kepercayaan dan sikap proaktif bawahanya. Pemimpin karismatik adalah pemimpin yang mewujudkan atmosfir motivasi atas dasar komitmen dan identitas emosional pada visi, filosofi, dan gaya mereka dalam diri bawahanya (Ivancevich, 2007).

Secara sederhana, secara sederhana dapat dijelaskan perbedaan antara pemimpin transformasional, pemimpin transaksional dan pemimpin karismatik, yang dapat diidentifikasi dalam tabel berikut (Sashkin, Marshall, 2011):

Tabel 1

Perbandinagn Karakteristik Model Kepemimpinan

\begin{tabular}{ccc}
\hline Kepemimpinan Karismatik & Kepemimpinan & Kepemimpinan \\
& Transaksional & Transformasional \\
\hline Ketaatan melalui identifikasi, & Kerelaan dengan ekspektasi & Internalisasi nilai-nilai bersama \\
dengan ekspektasi menjadi & akan imbalan (atau & yang menjadi pedoman tindakan \\
berkuasa seperti pemimpin & menghindari hukuman) & \\
\hline
\end{tabular}


Penelitian-penelitian terdahulu yang telah dilakukan masih membahas kepemimpinan bersifat umum dalam hubungannya dengan emlpoyee engagement. Dan juga keterkaitan model kepemimpinan tertentu dengan employee engagement. Pada penelitian terdahulu Belum ditemukan penelitian yang membandingkan berbagai model kepemimpinan hubungannya dengan employee engagement.

Oleh karena itu, berkenaan dengan latar belakang di atas maka tujuan penelitian ini adalah: (1) Untuk mengetahui bagaimana Employee Engagement Guru SLTA Se Kecamatan Salaman Kabupaten Magelang; (2) Untuk mengetahui bagaimana model kepemimpinan kepala sekolah SLTA Se Kecamatan Salaman Kabupaten Magelang;(3) Untuk Mengetahuai bagaimana pengaruh model kepemimpinan kepala sekolah terhadap Employee Engagement guru SLTA Se Kecamatan Salaman Kabupaten Magelang.

\section{METODE}

Penelitian yang digunakan adalah penelitian penjelasan (explanatory). Pendekatan penelitian yang digunakan dalam penelitian ini adalah pendekatan kuantitatif (Sugiyono, 2015). Populasi dalam penelitian ini berjumlah 142 guru SMA/SMK di Kecamatan Salaman. Sedangkan penentuan sampel menggunakan proporsional randum sampling. Teknik penentuan anggota populasi untuk mansuk manjadi sampel penelitian dilaksanakan dengan mengguakan urutan genap ganjil. Daftar guru yang bernomor ganjil dijadikan sebagai sampel penelitian. Oleh karena itu maka Sampel penelitian ini diambil 50\% dari populasi, sehingga sampel dalam penelitian sebanyak 71 orang. Sedangkan instrumen yang digunakan mengambil sampel dengan menggunakan angket. Teknik analisis data yang digunakan adalah : (1) Analisis Deskriptif Analisis ini dipakai untuk mendeskripsikan karakteristik daerah penelitian, responden, dan distribusi item masing-masing variabel; (2) Analisis Regresi Linier Berganda Analisis regresi linier berganda digunakan untuk menyatakan seberapa besar pengaruh naik turunnya nilai variabel terikat terhadap dua atau lebih variabel bebas; dan (3) Analisis Regresi Parsial Untuk mengetahui signifikan atau tidaknya pengaruh dari masing-masing variabel bebas $(X)$ terhadap variabelvariabel terikat $(\mathrm{Y})$.

\section{HASIL DAN PEMBAHASAN}

\section{Hasil}

1. Employe Engagement guru SLTA Se Kecamatan Salaman Kabupaten Magelang.

Variabel Employe Engagement Guru diperoleh dengan menjumlahkan total skor Employe Engagement dan selanjutnya dikategorikan menjadi empat kategori, yaitu Sangat Baik, Baik, Cukup, dan Kurang. Hasil analisis statistik deskriptif tentang Employe Engagement Guru SLTA Se Kecamatan Salaman Kabupaten Magelang dapat dilihat pada Tabel 2 sebagai berikut: 
Tabel 2

Employe Engagement Guru SLTA Se Kecamatan Salaman Kabupaten Magelang

\begin{tabular}{ccccc}
\hline No & Interval & Jumlah & Prosesntase & Predikat \\
\hline 1 & $>80$ & 102 & $51 \%$ & Sangat Baik \\
2 & $61-80$ & 98 & $49 \%$ & Baik \\
3 & $40-60$ & 10 & $5 \%$ & Kurang Baik \\
4 & $<40$ & 0 & 0 & Tidak Baik \\
\hline
\end{tabular}

Berdasarkan tabel di atas, diketahui bahwa guru memiliki Employe Engagement dengan variative dan berbeda-beda. Berdasarkan 200 responden yang diteliti, 51\% responden (102 guru) memiliki Employe Engagement sangat baik, 49\% responden (98 guru) memiliki Employe Engagement guru baik, 5\% responden (10 guru) memiliki Employe Engagement kurang baik dan tidak ada responden guru yang memiliki Employe Engagement yang tidak baik.

Berdasarkan analsis data dari masing-masing indikator, tergambarkan bahwa Employe Engagement guru pada kategori tinggi. Hal ini berarti mayoritas guru bekerja dengan semangat dan mereka merasa memiliki hubungan yang mendalam dengan sekolah tempat mereka bekerja, para guru mendorong inovasi dan mendorong kemajuan sekolah. Mereka bekerja dengan usaha ekstra dan lebih dari apa yang diharapkan. Keseluruhan dimensi Employe Engagement menunjukkan hasil yang bagus, hal ini menunjukkan bahwa Employe Engagement terjadi secara menyeluruh pada setiap dimensinnya, dan dimensi yang paling tinggi skornyanya adalah dimensi Dedikasi (Dedication), yaitu dedikasi yang mengacu pada perasaan yang penuh makna, antusias, inspirasi, kebanggaan di dalam keterlibatan membangun sekolah.

\section{Model kepemimpinan Kepala Sekolah SLTA Se Kecamatan Salaman Kabupaten Magelang}

Variabel Kepemimpinan Kepala Sekolah dalam penelitian ini diperoleh dengan menjumlahkan total skor Kepemimpinan Kepala Sekolah dan selanjutnya dikategorikan menjadi 4 kategori, yaitu sangat baik, baik, cukup, kurang dan sangat kurang. Hasil analisis statistik deskriptif tentang Kepemimpinan Kepala Sekolah SLTA Se Kecamatan Salaman Kabupaten Magelang dapat dilihat pada Tabel 3 berikut:

Tabel 3

Kepemimpinan Kepala Sekolah SLTA Se Kecamatan Salaman Kabupaten Magelang

\begin{tabular}{ccccc}
\hline No & Interval & Jumlah & Prosesntase & Predikat \\
\hline 1 & $>80$ & 110 & $55 \%$ & Transformasional \\
2 & $61-80$ & 87 & $44 \%$ & Kharismatik \\
3 & $40-60$ & 2 & $1 \%$ & Transaksional \\
\hline
\end{tabular}

Berdasarkan tabel di atas, diketahui bahwa guru memiliki persepsi yang berbedabeda tentang kepemimpinan kepala sekolah. Berdasarkan 200 responden yang diteliti, $55 \%$ responden (110 guru) menyatakan kepemimpinan kepala memiliki model kepemimpinan Transformatif, 44\% responden (87 guru) menyatakan kepemimpinan kepala sekolah memeiliki model kepemimpinan Kharismatik, 1\% responden (2 guru) menyatakan kepemimpinan kepala sekolah memiliki model kepemimpinan Transaksional. 
Berdasarkan analsis data dari masing-masing indikator, tergambarkan bahwa mayoritas guru melihat bahwa Model kepemimpinan kepala sekolah dengan menggunakan model Transformatif. Hal ini berarti mayoritas guru melihat bahwa kepemimpinan kepala sekolah sangat efektif membawa pada kemajuan sekolah.

Keseluruhan dimensi Kepemimpinan transformatif menunjukkan hasil yang bagus, hal ini menunjukkan bahwa kepemimpnan transformasional terjadi secara menyeluruh pada setiap dimensinnya, dan dimensi yang paling tinggi skornyanya adalah dimensi Motivator yang Inspirasional. Pada bagian ini maka Kepala Sekolah menggunakan kekuasaan secara positif dan bertanggung jawab kepada sekolah dan guru serta karyawan yang membutuhkan pengakuan, penghargaan, dan pencapaian prestasi untuk mendorong motivasi dan kepuasan.

\section{Pengaruh model kepemimpinan Kepala Sekolah terhadap employe engagement guru SLTA Se Kecamatan Salaman Kabupaten Magelang.}

Hasil analisis data pengaruh model kepemimpinan kepala sekolah terhadap Employee Engagement guru SLTA Se Kecamatan Salaman Kabupaten Magelang dapat dilihat pada Tabel 4 berikut:

Tabel 4

Pengaruh Model Kepemimpinan Kepala Sekolah Terhadap Employe Angegement Guru SLTA Se Kecamatan Salaman Kabupaten Magelang

\begin{tabular}{|c|c|c|c|c|c|c|}
\hline No & Koefisien Jalur & Beta & Uji t $p$ value & Koefisien & Ket. & Proporsi Pengaruh \\
\hline 1 & $\mathrm{X} 1 \longrightarrow \mathrm{Y}$ & 0,456 & 0.000 & 0,205 & Sign & $20,5 \%$ \\
\hline 2 & $\mathrm{X} 2 \longrightarrow \mathrm{Y}$ & 0,483 & 0.000 & 0,341 & Sign & $34,1 \%$ \\
\hline 3 & $\mathrm{X} 3 \longrightarrow \mathrm{Y}$ & 0,102 & 0.000 & 0,049 & Sign & $4,9 \%$ \\
\hline
\end{tabular}

Berdasarkan analisis data yang telah dilakukan sebagaimana Tabel 4 di atas diketahui bahwa nilai koefisien kepemimpinan kharismatik kepala sekolah terhadap Employe Angegement $(X 1-Y)$ menunjukkan angka sebesar 0,456 dan nilai koefisien kepemimpinan transformatif kepala sekolah terhadap Employe Angegement (X2-Y) sebesar 0,483, serta nilai koefisien kepemimpinan transaksional kepala sekolah terhadap Employe Angegement (X3-Y) sebesar 0,102. Hal ni menunjukkan bahwa nilai kepemimpinan transformatif memiliki pengaruh lebih tinggi terhadap Employe Angegement dibandingkan model kepemimpinan kharismatik dan kepemimpinan transaksional.

Selanjutnya jika dilihat dari proporsi pengaruh model kepemimpinan kepala sekolah terhadap Employe Angegement guru dapat dilihat bahwa Proporsi pengaruh kepemimpinan kharismatik kepala sekolah terhadap Employe Angegement (X1-Y) menunjukkan angka sebesar 20,5 persen dan Proporsi pengaruh kepemimpinan transformatif kepala sekolah terhadap Employe Angegement guru (X2-Y) sebesar 34,1\%, serta Proporsi pengaruh kepemimpinan transaksional kepala sekolah terhadap Employe Angegement (X3-Y) 4,1\%.

Berdasarkan analisis data yang telah dilakukan sebagaimana Tabel 5 di atas diketahui bahwa proporsi pengaruh kepemimpinan transformatif kepala sekolah terhadap Employe Angegement guru ternyata lebih tinggi pengaruhnya dibandingkan dengan kepemimpinan kharismatik dan kepemimpinan transaksional. 


\section{Pembahasan}

Berdasarkan hasil analisis di atas maka dapat dijelaskan pada pembahasan berikut: Berdasarkan analisis data yang telah dilakukan sebagaimana Tabel 4 di atas diketahui bahwa nilai koefisien kepemimpinan kharismatik kepala sekolah terhadap Employe Angegement (X1Y) menunjukkan angka sebesar 0,456 dan nilai koefisien kepemimpinan transformatif kepala sekolah terhadap Employe Angegement (X2-Y) sebesar 0,483, serta nilai koefisien kepemimpinan transaksional kepala sekolah terhadap Employe Angegement (X3-Y) sebesar 0,102 . Hal ni menunjukkan bahwa nilai kepemimpinan transformatif memiliki pengaruh lebih tinggi terhadap Employe Angegement dibandingkan model kepemimpinan kharismatik dan kepemimpinan transaksional.

Selanjutknya jika dilihat dari proporsi pengaruh model kepemimpinan kepala sekolah terhadap Employe Angegement guru dapat dilihat bahwa Proporsi pengaruh kepemimpinan kharismatik kepala sekolah terhadap Employe Angegement (X1-Y) menunjukkan angka sebesar 20,5 persen dan Proporsi pengaruh kepemimpinan transformatif kepala sekolah terhadap Employe Angegement guru (X2-Y) sebesar 34,1\%, serta Proporsi pengaruh kepemimpinan transaksional kepala sekolah terhadap Employe Angegement (X3-Y) 4,1 \%.

Berdasarkan analisis data yang telah dilakukan sebagaimana Tabel 4 di atas diketahui bahwa proporsi pengaruh kepemimpinan transformatif kepala sekolah terhadap Employe Angegement guru ternyata lebih tinggi pengaruhnya dibandingkan dengan kepemimpinan kharismatik dan kepemimpinan transaksional.

Hasil penelitian di atas seseuai dengan penelitian-penelitian sebelumnya. Employee Engagement pada dasarnya terdiri dari aspek kognitif, afektif maupun perilaku. Karyawan yang engaged memiliki keyakinan dan mendukung tujuan organisasi, memiliki rasa memiliki, merasa bangga terhadap organisasi dimana dia bekerja dan mempunyai keinginan untuk berkembang dan bertahan dalam organisasi (Bakker, A.B., Leiter, 2005).

Employee Engagement yang buruk akan berpengaruh terhadap produktivitas dan kepuasan pelanggan, dan juga meningkatkan turnover (Permana, 2010).

Guru yang memiliki Employee Engagement, dia memilikiketerikatan terhadap pekerjaan dan sekolah tempat mereka bekerja, artinya guru selalu antusias, semangat dan bergairah dalam mencapai target kerja yang diberikan, mereka menyatakan akan tetap bekerja di sekolahnya saat ini walaupun ada tawaran lain, mereka merasa senang dan dihargai dengan pekerjaannya saat ini kemudian mereka juga merasa yakin akan sukses dengan bekerja di tempat mereka bekerja (Sinta Yulianti, Eeng Ahman, 2018).

Seorang karyawan merasa engaged ketika mereka menemukan makna dan motivasi dalam pekerjaannya, menerima dukungan interpersonal yang positif, dan berada pada lingkungan kerja yang berfungsi secara efisien (Gaddi, 2004). Oleh karena itu salah satu faktor yang dapat meningkatkan engagement, diantaranya adalah perilaku yang menunjukkan dukungan dan motivasi. Dukungan dan motivasi dalam bekerja dapat diberikan oleh seorang pemimpin kepada bawahannya, karena kepemimpinan merupakan penggerak dan penentu perjalanan suatu organisasi (Yukl, 2006). Kepemimpinan kepala sekolah yang baik akan menghasilkan kepuasan kerja bagi guru, karena kepala sekolah dapat membimbing, dan membina guru dengan sabar dan penuh perhatian. Demikian juga guru kurang puas terhadap kepemimpinan kepala sekolahnya karena kepala sekolah sering meninggalkan sekolah, kurang membimbing, kurang perhatian dan kurang sabar dalam kepemimpinannya (Nani Hanifah, 2021). Jadi keterlibatan guru dalam sekolah sangat dipengaruhi model kepemimpinan kepala sekolah(Ardiansyah, 2020). 
Northouse (Northhouse, 2013) mengungkapkan bahwa kepemimpinan transformasional merupakan proses di mana orang terlibat dengan orang lain, dan menciptakan hubungan yang meningkatkan motivasi dan moralitas dalam diri pemimpin dan pengikut. Jenis pemimpin ini memiliki perhatian pada kebutuhan dan motif pengikut, serta mencoba membantu pengikut mencapai potensi terbaik mereka.

Tim, Barker, Xanthopoulou menemukan bahwasanya kepemimpinan transformasional berhubungan positif dengan employee engagement. Hubungan tersebut dimediasi oleh tingkat optimisme yang dimiliki karyawan setiap harinya. Sementara itu, bahwasanya terdapat korelasi yang signifikan antara kepemimpinan transformasional dengan engagement pengikut. Antara employee engagement dan efektivitas manajer dimediasi oleh variabel efikasi diri manajer (Tims, M., Bakker, A.B., Xanthopoulou, 2011).

Markos dan Sridevi (Sinta Yulianti, Eeng Ahman, 2018), mengungkapkan bahwa komunikasi dua arah antara pemimpin dan pegawai, perhatian pemimpin terhadap kesejahteraan dan perkembangan pegawai, dapat meningkatkan employee engagement. Pendapat yang sejalan juga dikemukakan dalam hasil penelitian Datche bahwa gaya kempemimpinan merupakan faktor yang dapat meningkatkan level employee engagement.

\section{SIMPULAN DAN SARAN}

\section{Simpulan}

Berdasarkan hasil analisis di atas maka hasil penelitian ini dapat diambil beberapa simpul, diantaranya bahwa guru memiliki Employe Engagement dengan variative dan berbedabeda. Berdasarkan 200 responden yang diteliti, 51\% responden (102 guru) memiliki Employe Engagement sangat baik, 49\% responden (98 guru) memiliki Employe Engagement guru baik, 5\% responden (10 guru) memiliki Employe Engagement kurang baik dan tidak ada responden guru yang memiliki Employe Engagement yang tidak baik. Disamping itu juga guru memiliki persepsi yang berbeda-beda tentang kepemimpinan kepala sekolah. Berdasarkan 200 responden yang diteliti, 55\% responden (110 guru) menyatakan kepemimpinan kepala memiliki model kepemimpinan Transformatif, 44\% responden (87 guru) menyatakan kepemimpinan kepala sekolah memeiliki model kepemimpinan Kharismatik, 1\% responden (2 guru) menyatakan kepemimpinan kepala sekolah memiliki model kepemimpinan Transaksional. Selanjutnya Nilai koefisien kepemimpinan kharismatik kepala sekolah terhadap Employe Angegement (X1-Y) menunjukkan angka sebesar 0,456 dan nilai koefisien kepemimpinan transformatif kepala sekolah terhadap Employe Angegement (X2-Y) sebesar 0,483, serta nilai koefisien kepemimpinan transaksional kepala sekolah terhadap Employe Angegement (X3-Y) sebesar 0,102 . Hal ni menunjukkan bahwa nilai kepemimpinan transformatif memiliki pengaruh lebih tinggi terhadap Employe Angegement dibandingkan model kepemimpinan kharismatik dan kepemimpinan transaksional. Jika dilihat dari proporsi pengaruh model kepemimpinan kepala sekolah terhadap Employe Angegement guru dapat dilihat bahwa Proporsi pengaruh kepemimpinan kharismatik kepala sekolah terhadap Employe Angegement (X1-Y) menunjukkan angka sebesar 20,5 persen dan Proporsi pengaruh kepemimpinan transformatif kepala sekolah terhadap Employe Angegement guru (X2-Y) sebesar 34,1\%, serta Proporsi pengaruh kepemimpinan transaksional kepala sekolah terhadap Employe Angegement (X3-Y) $4,1 \%$. Dan kesimpulan terakhir dari penelitian ini adalah proporsi pengaruh kepemimpinan transformatif kepala sekolah terhadap Employe Angegement guru ternyata lebih tinggi pengaruhnya dibandingkan dengan kepemimpinan kharismatik dan kepemimpinan transaksional. 


\section{Saran}

Dari hasil penelitian di atas maka ddidapatkan beberapa saran bagi sekolah, adalah sebagai berikut: (1) Kepala Sekolah sebaiknya sering berdiskusi dengan guru dan karyawan. Hal ini penting untuk memberikan informasi berkaitan perkembangan terkini tentang kelembagaan dan juga untuk mendapatkan informasi dari guru dan karyawan tentang berbagai permasalahan yang ada di sekolah; dan (2) Pertemuan berkala dirasa penting untuk membahas berbagai kendala dan evaluasi yang terjadi di lapangan. Selain itu juga saran bagi peneliti selanjutnya adalah diharapkan peneliti-peneliti selanjutnya juga mempertimbangkan faktor-faktor lain di luar aspek kepemimpinan kepala sekolah.

\section{Implikasi}

Berdasarkan kesimpulan di atas maka implikasi yang diperoleh adalah bahwa kepemimpinan kepala sekolah yang baik akan menjadikan guru memiliki employee engagement yang baik. Oleh karena itu kepala sekolah mempunyai kewajiban menumbuhkan employee engagement bagi para guru. Hal ini penting karena employee engagement akan membuat organisasi (sekolah) semakin sehat dan juga menjadikan lembaga semakin memiliki kinerja yang baik.

\section{ACKNOWLEDGEMENT}

Terima kasih kami ucapkan kepada: (1) Kepala SMK Se Kecamatan Salaman Kabupaten Magelang, yang telah berkenan memberi ijin untuk melaksakan penelitian pada sekolah yang dipimpin; (2) Dinas Pendidikan dan Kebudayaan Propinsi Jawa Tengah yang telah memberi kesempatan kepada peneliti untuk berdiskusi tentang perkembangan sekolah; (3) Program Pascasarjana Universitas Muhammadiyah Magelang yang telah memberikan masukan dan diskusi tentang paradigma penelitian; dan (4) Redaktur Jurnal Sosio e-Kons, yang telah berkenan menerbitkan karya ilmiah ini.

\section{DAFTAR PUSTAKA}

Agustinus Hermino. (2014). Kepemimpinan Pendidikan di Era Globalisasi. Yogyakarta: Pustaka Pelajar.

Ardiansyah, T. (2020). Employee Engagement Terhadap Employee Performance (Sebuah Studi Literatur). Sosio E-Kons, 12(02), 156. https://doi.org/10.30998/sosioekons.v12i02.6444

Bakker, A.B., Leiter, M. . (2005.). Work Engagement: A Handbook Of Essential Theory And Research (pp.181-196). Psychology press: New York. Diunduh pada.

Bakker dan Schaufeli. (2003). Job demands and job resources as predictors of absence duration and frequency. Journal of Vocational Behavior, 19(2).

Didin Kurniadi. (2012). Manajemen Pendidikan, Konsep dan Prinsip Pengelolaan Pendidikan. Yogyakarta: Ar-Ruz Media.

Dwi Ari Wibawa. (2012). Kepemimpinan Transaksional dan Kepemimpinan Transformasional, 2012, h. 9.

Eka Dian Aprilia, O. K. (2020). Workplace Spirituality And Employe Engagement Among High School Teachers In Banda Aceh. Jurnal Psikologi, 19(1), 61-71.

Gaddi, R. (2004). Leadership And Employee Engagement: When Employees Give Their all. Hani Handoko. (1999). Manajemen (Edisi Kedu). Yogyakarta: BPFE. 
Husaini Usman. (2014). Manajemen: Teori, Praktik, dan Riset Pendidikan. Jakarta: Bumi Aksara. Ike Agustina. (2020). Kebahagiaan Autentik dan Keterikatan Kerja Guru di Sekolah Inklusi. PSIKOLOGIKA Volume 25 Nomor 2 Juli 2020. 167-184. PSIKOLOGIKA, 25(2), 167-184.

Imam Mahalli, A. H. (2012). Pengelolaan Pendidikan: Konsep, Prinsip, dan Aplikasi dalam Mengelola Sekolah dan Madrasah. Yogyakarta: Kaukaba.

Ivancevich. (2007). Perilaku dan Manajemen Organisasi. Jakarta: Erlangga.

Lianto Vilency Virani, D. (2015). Pengaruh Transformasional Leadership Terhadap Competitive Advantage Melalui Learining Organiz ation Sebagai Variabel Intervening Pada Perusahaan Ritel Berskala International dan Nasional di Surabaya. Bussines Accounting Review, 3(1), 294-308.

Nani Hanifah. (2021). Hubungan Kepemimpinan Kepala sekolah Dengan Kepuasan Guru di SDN Jatisampurna VIII Bekasi. Sosio E-Cons, 13(1), 26-37.

Ni Luh Putu Astuti, Ni Putu Sri Harta Mimba, N. M. D. R. (2016). Pengaruh Employe Engagement pada Kinerja Bendahara Pengeluaran dengan Kepemimpinan Transformasional sebagai Pemoderasi. E-Jurnal Ekonomi Dan Bisnis Universitas Udayana, 5(12), 4057-4082.

Northhouse, P. G. (2013). Kepemimpinan dari Teori ke Praktik. Jakarta: PT INDEKS Kelompok GRAMEDIA.

Pandu Djati Sentano, Sugih Arijanto, Y. Y. (2016). Peningkatan Kepuasan Kerja Dan Employee Engagement Pengajar Dan Karyawan Di Yayasan Pendidikan " $X$ " Bandung. Reka Integra. Jurnal Online Institut Teknologi Nasional. Jurusan Teknik Industri Itenas, 4(1).

Permana, N. I. K. (2010). Mempertahankan talent untuk meraih keunggulan kompetitif. Jakarta: PPM.

Prasetyono, H., \& Ramdayana, I. P. (2020). Pengaruh servant leadership, komitmen organisasi dan lingkungan fisik terhadap kinerja guru. Jurnal Akuntabilitas Manajemen Pendidikan, 8(2), 108-123. https://doi.org/10.21831/jamp.v8i2.28458

Prasetyono, H., Ramdayana, I. P., \& Estiningsih, W. (2020). Peningkatan Kinerja Guru SMK melalui Lingkungan Kerja dengan Mengoptimalkan Efektifitas Kepemimpinan dan Komitmen Tugas. Jurnal Manajemen Dan Supervisi Pendidikan, 4(3), 255-266.

Raihan. (n.d.). Kepemimpian Sekolah Transformasional. Yogyakarta: PT. LKS Printing Cemerlang.

Rizqiani, A., Syamsun, M., \& Dirdjosuparto, S. (2011). dan Motivasi Kerja Guru terhadap Komitmen Kerja Guru ( Studi Kasus : SDIT Ummul Quro ’ Kota Bogor ). (66), 61-69.

Santosa, T. E. C. (2012). Memahami dan Mendorong Terciptanya Employee Engagement dalam Organisasi. Jurnal Manajemen, 11(2), 209-222.

Sashkin, Marshall, M. G. S. (2011). Prinsip-Prinsip Kepemimpinan, Erlangga. Jakarta: Erlangga.

Sinta Yulianti, Eeng Ahman, S. (2018). Pengaruh Kepemimpinan Transformasional dan Komunikasi Internal Terhadap Employee Engagement. Jurnal IImu Manajemen \& Bisnis, 9(1).

Sisly Duri Afryana. (2018). Sisly Duri Afryana, "Pengaruh Sense Of Belonging Terhadap Employee Engagement (Studi di Bandung Echnopark)",. Jurnal Indonesia Membangun, 17(2).

Sondang P.Siagian. (2009). Tipe-Tipe Kepemimpinan. Jakarta: Gramedia Utama.

Stephen P. Robbins \& Timothy A.Judge. (2008). Perilaku Organisasi. Jakarta: Salemba Empat.

Sugiyono. (2015). Metode Penelitian Pendidikan, Pendekatan Kuantitatif, Kualitatif dan R\&D. Bandung: Alfa Beta.

Tim Pengembang IImu Pendidikan FIP-UPI. (2007). IImu dan Aplikasi Pendidikan. Bandung: Imperial Bakti Utama. 
Tims, M., Bakker, A.B., Xanthopoulou, D. (2011). Do Transformational Leaders Enhance Their Follower's Daily Work Engagement?. The Leadership Quarterly. 22(1), 121-131.

Veithzal Rizai dan Arvian Arifi. (2015). Islamic Leadership (Membangun Super Leadership Melalui Kecerdasan Spiritual). Jogjakarta.

Viqi Anggreana. (2015). Pengaruh Budaya Organisasi Dan Kepemimpinan Terhadap Employee Engagement Pada Pegawai Negeri Sipil Di Kantor Bupati Bagian Umum Setda Kabupaten Siak. Jom FEKON, 2(2).

Yukl, G. (2006). Leadership in Organizations Sixth Edition. New Jersey: Pearson Education, Inc. 